AUTHOR:

A.H. Kalie Strydom ${ }^{1}$

\section{AFFILIATION:}

${ }^{1}$ Retired Director of the Free State Higher Education and Training Trust

\section{CORRESPONDENCE TO: Kalie Strydom}

\section{EMAIL:}

strydomah@telkomsa.net

\section{POSTAL ADDRESS:}

P0 Box 43571, Heuwelsig 9332, South Africa

\section{HOW TO CITE:}

Strydom AH. Professor Benito Makhala Khotseng (1948-2015): A passionate, humanitarian educationist. $S$ Afr J Sci. 2015;111(5/6), Art. \#a0097, 1 page. http://dx.doi. org/10.17159/sajs.2015/a0097

\title{
Professor Benito Makhala Khotseng (1948-2015): A passionate, humanitarian educationist
}

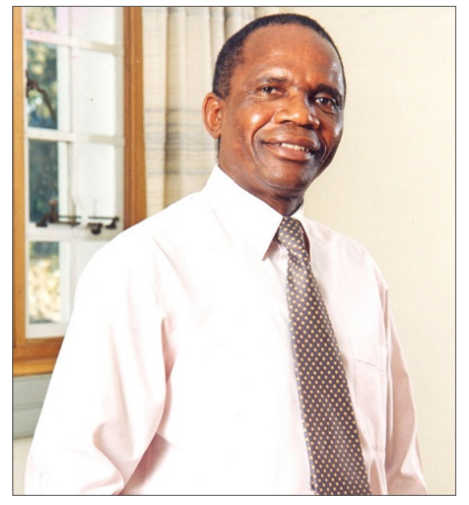

Professor Benito Khotseng died on 4 January 2015 at the age of 67, after suffering from ischaemic heart disease. A memorial service was held at the University of the Free State on 12 January 2015 and he was buried on 17 January 2015 at his homestead in Matatiele in the Eastern Cape.

Benito attained his primary education at Queen Mary Primary School and his secondary education at Moshoeshoe Secondary School. In 1969, he obtained a BA degree in Education from the University of the North, and went on to complete a BEd from the University of South Africa (Unisa) in 1974. As a principled thinker who was passionate about education and training, Benito Khotseng continued his studies and completed a $\mathrm{PhD}$ at the University of Natal in 1990. His thesis was titled Polytechnic University and its contribution to manpower development in South Africa, clearly indicating his commitment to initiating developmental opportunities for disadvantaged learners at all levels.

Benito started his career as an assistant teacher at Mount Hargreaves High School in 1971. In 1972, he was promoted to senior assistant teacher at Bensonvale High School where he taught Biology and Sesotho to Grade 11 and 12 learners. In 1974, he became a Vice-Principal at Bethlehem High School, where he also taught Biology, English and History to Grade 11 and 12 learners.

In 1976, Benito joined the Bonamelo Teachers College as Rector, a position which he occupied until 1978. In 1979, he joined the Qwaqwa Government Service as an education planner, and from 1991 to 1993, served the University of the North (Qwaqwa Campus) as a lecturer in History and Philosophy of Education. He joined the University of the Free State as a senior director managing strategic developmental programmes in 1993 doing trailblazing work in the interest of previously disadvantaged students and leading transformation at the University of the Free State. His principled and balanced leadership led to his promotion to Vice Rector/Deputy Vice Chancellor Student Affairs in 1996 - a position he held until 2003 when he joined the University of Cape Town. Benito served as a Deputy Vice Chancellor at the University of Cape Town until 2004. Benito was a visiting professor at Seton Hall University in New Jersey (USA) and also held positions as a senior researcher for the University of the Western Cape and as a consultant to the South African Management Development Institute. He attended numerous programmes at a number of universities, including the University of Huddersfield in the UK, Ohio State University in the USA, Harvard University, the National Coalition Building Institute in Washington DC, and the Indiana University of Indianapolis. Benito also presented research papers at many conferences in South Africa and abroad.

Benito dedicated his life to serving his community and country, and assumed leadership positions in various committees and groups around the country. He served as a chairperson in the Orange Free State Education Aid, the NECC Orange Free State, and the UDUSA Qwaqwa branch from 1985 to 1990. He was the treasurer of the Thusano Mobil Bursary Fund in Qwaqwa from 1990 to 1993, a consulting editor of Perspectives in Education between 1992 and 1995, a consulting editor of the South African Journal of Higher Education, and was the professional coordinator of the National Commission on Higher Education between 1995 and 1996. Furthermore, Benito was an International Advisory Board Member for the Department of Quality in Higher Education at the University of Birmingham in the UK.

Benito served on numerous boards and trusts, including the Matla Trust, the Trustees of Education with Enterprise, the Durban College of Education (1995-2001), the Financial Aid Scheme (2000-2003) and the Higher Education Quality Committee of the Council on Higher Education (2001-2005). He was elected as a Member of the Academy of Science of South Africa in 1996 and chaired the Free State Higher Education and Training Trust for many years until 2010. In addition to his involvement in community projects, Benito raised funds for student development, especially master's and doctoral programmes - between 1994 and 2000, he raised over USD27 million.

Benito contributed substantially to the body of knowledge of South Africa. Amongst others, he co-authored Kenton Vintage (1994), Apartheid Education and Popular Struggles (1991), Mmane - Poetry Analysis for Std. 10 (1991) and Mphatlalatsane Language Series - Std. 3, 4, 5, \& 6 (1986). He also published in and contributed to accredited journals on subjects ranging from 'Rethinking the nature of the university in a post-apartheid South Africa', 'Universities and challenges of nation-building in the new South Africa' and 'Promoting multiculturalism at the university campus'.

Benito won numerous awards for his huge contribution to the body of knowledge in the country and around the world. He received a US-South Africa Faculty Fellowship in 1989, a Southern Book Publishers award for Perspective on Higher Education in 2002, and was named Bloemfonteiner of the Month in April 1996. He received a certificate of recognition for the excellent work done for the University through the Multicultural Project in 1998, from the University of the Free State, and a Free State Teachers Association Honorary Membership Award for Outstanding Performance and Service Delivery in Education in 1999. He was also given an Honorary Member Award for Service and Excellence from the Golden Key International Honour Society in 2002.

His family and church were central to his life and his three daughters - Nthabiseng, Manana and Matshidiso - are not only professionally successful but also are dedicated, like their father, to education and the community. Benito will be sorely missed, but his legacy will be the considerable contributions he has made to higher education in South Africa. 